\title{
Diversity and some phenotypic characters of Joha rice (Oryza sativa L.) varieties cultivated in Bongaigaon district of Assam, India
}

\author{
Ranu Roy \\ Department of Botany, Birjhora Mahavidyalaya, Bongaigaon, Assam, 783380 \\ E-mail: ranuroy_bng@rediffmail.com
}

[Received 23.07.2018; Revised 21.12.2018; Accepted 23.12.2018; Published 31.12.2018]

\begin{abstract}
Farmers in different localities of Bongaigaon area still cultivate traditional rice varieties in their farming system. Besides different rice varieties, the farmers also cultivate Joha rice, commonly known as 'Bhog dhan'. To see the diversity of Joha rice and its phenotypic characters, a field study was made. Seven different Joha rice varieties were seen which are being cultivated in different localities. In the present study, 16 different phenotypic characters were studied along with protein concentration. It was found that though all the seven varieties of Joha rice were more or less similar but each variety showed some unique characteristics which may be utilized for identification of different varieties.
\end{abstract}

Key words: Joha rice, Bongaigaon, Phenotypic characters

\section{INTRODUCTION}

The North-east India, including Assam, is recognized as a centre of the origin of rice and is endowed with exceptionally rich rice diversity. The indigenous germplasm of North-east India represents a wealth of valuable gene systems (Sharma et al. 1971). Variation in ecological conditions, ethnic diversity, diverse cultural practices and different quality preferences contribute to the diversity present in different types of rice. Assam is particularly rich in rice germplasm. About $70 \%$ of total agricultural land of Assam is used for rice cultivation (Das et al. 2010). The four categories of rice classified on the basis of the amount of rainfall and zonal distribution are $A h u$ rice (autumn rice), Sali rice (winter rice), Boro rice (summer rice), and $B a o$ rice (deep water rice). Among different categories of rice, scented rice enjoys a special demand and are highly valued. The North-eastern Region is also home to a large number of aromatic and other good quality rice varieties (Choudhury et al. 2013). This scented or aromatic rice of Assam is a unique class under Sali rice traditionally known as 'Joha'. The characteristic odor in scented rice is due to a compound named 2-acetyle-1pyrroline (Buttery et al. 1982). Due to this aroma this class of rice has high demand in domestic market and is used mainly for preparation of special dishes like kheer and pulao. It cooks non-sticky and tasty meals. Aroma of Joha rice is as appreciable as for the goodness of Basmati rice.

Joha rice is known for its super fine grain, good cooking qualities and excellent deliciousness. The yield from traditional varieties are low but farmers still continue to cultivate, even as they adopt newer varieties, because compared to modern varieties the yield from traditional varieties are reliable and prevents the risk of yield failure (Harwood 1979). The yield of Joha rice is also low.

Bongaigaon $\left(26^{\circ} 282 \mathrm{~N}\right.$ and $\left.89^{\circ} 962 \mathrm{E}\right)$ is an agriculturally rich district of Assam, India (Figure 1). The average annual rainfall is about $4632.2 \mathrm{~mm}$ (BGR, IOCL 2010). The large 


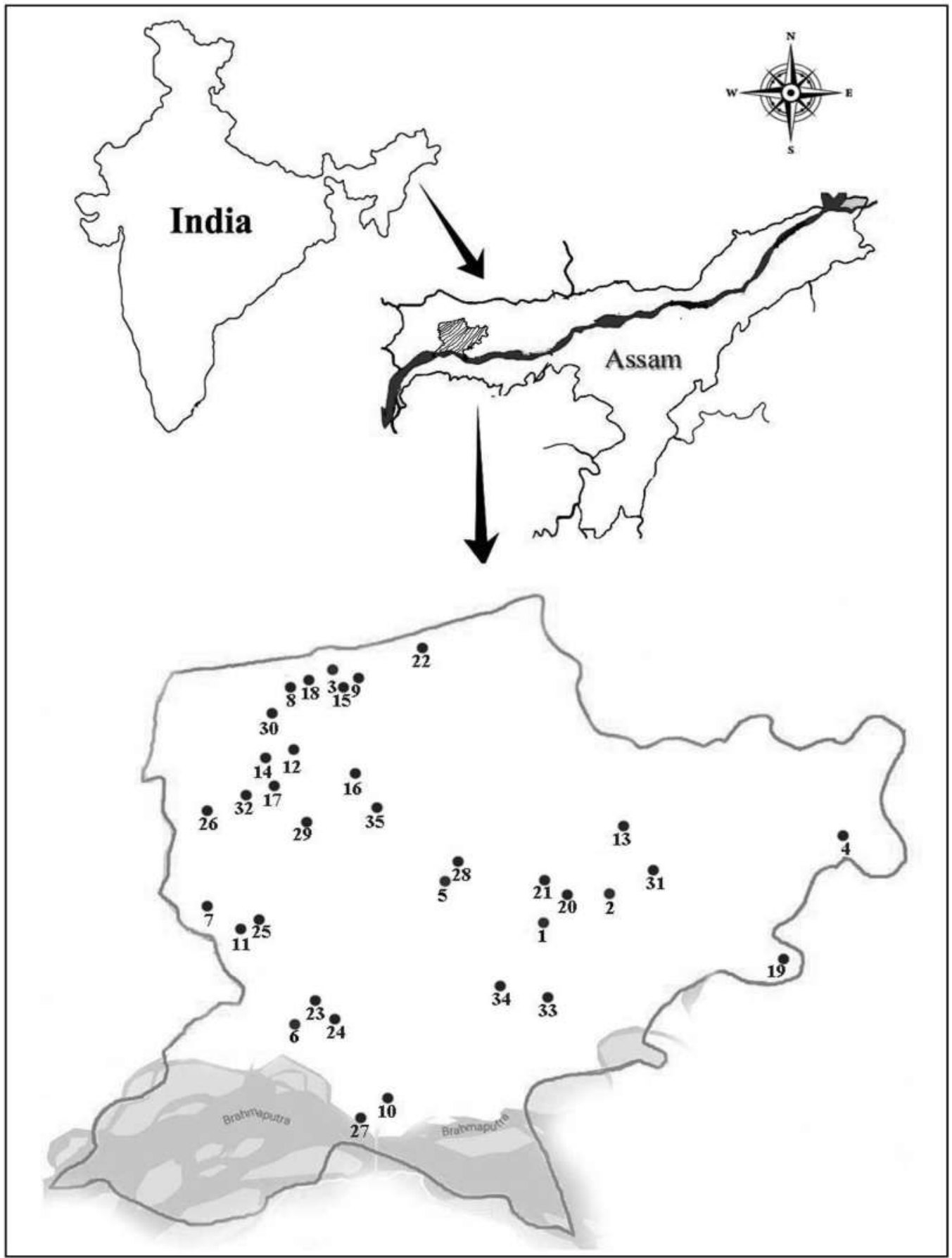

Figure 1. Location map of the Study Area [Paddy fields at: S1. Deohati; S2. Srijangram; S3. Poporagaon; S4. Adalaguri; S5. Khagarpur; S6. Shankarghola; S7. Nankargaon; S8. Dangtol; S9. Chitkagaon; S10. Kabaitari; S11. Kayethpara; S12. Dashimapara; S13. Sonakhuli; S14. Tengaigaon; S15. Meshpara; S16. Hatiutra; S17. Saonagaon; S18. Dolaigaon; S19. Kokila; S20. Sukani; S21. Tulungia; S22. Chaparakata; S23. Shakomura; S24. Nimagaon; S25. Talguri; S26. Bidyapur; S27. Jogighopa; S28. Nigamghola; S29. Kasharpara; S30. Kakragaon; S31. Barghola; S32. Panchapur; S33. Lalmati; S34. Shingimari; S35. Kahidoba 
area of paddy fields in the district is the primary earning source for the villagers. Bongaigaon district is also housing a large number of ethnic communities engaged in practicing various types of rice cultivation. Along with $A h u$, Sali and Bora, the farmers of this region cultivate a number of Joha rice varieties which are commonly known as 'Bhog dhan' in different localities. This rice plays an important role in different rituals of these localities and becomes an integral part in the local communities' culture. In order to see the diversity and phenotypic variation of characters in Joha rice varieties, a field study was conducted during the years 2011 to 2013.

\section{MATERIALS AND METHODS}

The period of study was restricted to November, December and January (rice harvesting periods) of 2011 to 2013. Thirty five localities of Bongaigaon district were selected randomly and named as S1, S2, S3, .........., S35. Along with regular field visits, farmers of different localities were approached and information was gathered about the local names and uses of different Joha rice varities. Rice grains and plants of different Joha rice were collected from all these localities and some phenotypic and biochemical characteristics were studied. The parameters included in the present study were:

- Height of plant,

- Length of panicle,

- Presence or absence of awn and their length,

- Length, breadth and width of the grain with husk and without husk,

- Weight and volume of 1000 grains with husk and without husk,

- Colour [standard DULUX colour chart] of the grains with husk and without husk; and

- Protein concentration.

\section{RESULT AND DISCUSSION}

During field survey seven different Joha rice varieties viz. Kalabhog, Ghagubhog, Benibhog, Tulsibhog, Katharibhog, Kewabhog and Shialbhog cultivated in different localities of Bongaigaon district were recognised and collected. All these 7 different varieties in the present study exhibited distinct variations in their phenotypic as well as bio-chemical characteristics.

The height of the plant ranged between $109.22 \pm 9.45 \mathrm{~cm}$ to $147.54 \pm 6.64 \mathrm{~cm}$. Tulsibhog was found to be the longest $(109.22 \pm 9.45 \mathrm{~cm})$ cultivar which was followed by Kalabhog, Ghogubhog, Shialbhog, Benibhog and Kewabhog. Katharibhog was the shortest $(147.54 \pm 6.64 \mathrm{~cm})$ height cultivar of this region.

Similarly, the length of the panicle also varied according to varietal type that ranged from $20.37 \pm 4.02 \mathrm{~cm}$ to $28.53 \pm 5.49 \mathrm{~cm}$. The longest spike was found in Tulsibhog $(28.53 \pm 5.49$ $\mathrm{cm})$ and shortest in Ghugubhog $(21.35 \pm 4.92 \mathrm{~cm})$.

Number of grains per panicle is also one important variable character for these varieties. The highest number of grains per spike was found in case of Shialbhog (130.2) and lowest number of grain per spike was found in Katharibhog (79.75). Except Ghugubhog and Tulsibhog, the grains of other varieties are with distinct awn with length ranged from $0.5 \mathrm{~cm}$ to $5.3 \mathrm{~cm}$. Kalabhog was found to have the longest $(5.3 \mathrm{~cm})$ awn (Table 1). 
Table 1. Numerical assessment of some important phenotypic characters in different Joha rice cultivated in different localities of Bongaigaon district

\begin{tabular}{|l|l|l|l|l|}
\hline $\begin{array}{l}\text { Varietal } \\
\text { name }\end{array}$ & $\begin{array}{l}\text { Height of } \\
\text { plant } \mathbf{( c m )}\end{array}$ & $\begin{array}{l}\text { Panicle length } \\
\mathbf{( c m )}\end{array}$ & $\begin{array}{l}\text { Number of } \\
\text { grain/panicle }\end{array}$ & $\begin{array}{l}\text { Awn length } \\
\mathbf{( c m )}\end{array}$ \\
\hline Kalabhog & $132.89 \pm 9.53$ & $23.32 \pm 4.88$ & $93.82 \pm 25.47$ & 5.3 \\
\hline Ghagubhog & $129.65 \pm 7.72$ & $21.35 \pm 4.92$ & $100.02 \pm 25.52$ & Absent \\
\hline Benibhog & $125.06 \pm 8.45$ & $20.37 \pm 4.02$ & $95.42 \pm 21.22$ & $\begin{array}{l}\text { Absent, rarely } \\
\text { present }\end{array}$ \\
\hline Tulsibhog & $147.54 \pm 6.64$ & $28.53 \pm 5.49$ & $112.49 \pm 18.02$ & Absent \\
\hline Katharibhog & $109.22 \pm 9.45$ & $23.66 \pm 6.71$ & $79.75 \pm 25.02$ & 5.0 \\
\hline Kewabhog & $112.22 \pm 10.45$ & $21.67 \pm 6.75$ & $85.75 \pm 25.02$ & 0.5 \\
\hline Shialbhog & $127.02 \pm 9.73$ & $22.5 \pm 4.01$ & $130.2 \pm 623.28$ & 0.2 \\
\hline
\end{tabular}

The Joha rice grains in Bongaigaon district were found to be short to medium and slender. The length of the grain (with husk) does not exceed $0.827 \mathrm{~mm}$. Similarly, the lengths of the grain (without husk) in all the varieties were less than $0.65 \mathrm{~mm}$. The longest grain (with husk) was observed in Kalabhog $(0.827 \pm 0.06 \mathrm{~mm})$, where the ratio of length: breadth: width was $0.827: 0.274: 0.221$. Shortest grain (with husk) was observed in Tulsibhog $(0.590 \pm 0.025 \mathrm{~mm})$, where the ratio between length: breadth: width was 0.590:0.224:0.173.

The longest grain (without husk) was observed in Kalabhog $(0.636 \pm 0.055 \mathrm{~mm})$ and the ratio of length: breadth: width was $0.636: 0.254: 0.035$. On the other hand, shortest grain (without husk) was observed in Tulsibhog $(0.438 \pm 0.032 \mathrm{~mm})$ and the ratio of length: breadth: width was 0.438:0.227:0.015 (Table 2).

Table 2. Phenotypic characters of grains (with and without husk) of different Joha rice varieties cultivated in Bongaigaon district

\begin{tabular}{|l|l|l|l|l|l|l|}
\hline Varietal & $\begin{array}{l}\text { Grain Length } \\
(\mathrm{mm}) \text { with } \\
\text { Nusk }\end{array}$ & $\begin{array}{l}\text { Grain } \\
\text { breadth }(\mathrm{mm}) \\
\text { with husk }\end{array}$ & $\begin{array}{l}\text { Grain } \\
\text { width }(\mathrm{mm}) \\
\text { with husk }\end{array}$ & $\begin{array}{l}\text { Grain length } \\
(\mathrm{mm}) \\
\text { without husk }\end{array}$ & $\begin{array}{l}\text { Grain breadth } \\
(\mathrm{mm}) \text { without } \\
\text { husk }\end{array}$ & $\begin{array}{l}\text { Grain width } \\
\text { (mm) without } \\
\text { husk }\end{array}$ \\
\hline Kalabhog & $0.827 \pm 0.060$ & $0.274 \pm 0.010$ & $0.221 \pm 0.007$ & $0.636 \pm 0.055$ & $0.254 \pm 0.035$ & $0.264 \pm 0.011$ \\
\hline Ghagubhog & $0.622 \pm 0.048$ & $0.282 \pm 0.006$ & $0.242 \pm 0.022$ & $0.454 \pm 0.051$ & $0.257 \pm 0.009$ & $0.231 \pm 0.013$ \\
\hline Benibhog & $0.703 \pm 0.045$ & $0.217 \pm 0.017$ & $0.166 \pm 0.018$ & $0.499 \pm 0.046$ & $0.189 \pm 0.029$ & $0.149 \pm 0.007$ \\
\hline Tulsibhog & $0.590 \pm 0.025$ & $0.224 \pm 0.014$ & $0.173 \pm 0.025$ & $0.438 \pm 0.032$ & $0.227 \pm 0.015$ & $0.151 \pm 0.003$ \\
\hline Katharibhog & $0.796 \pm 0.061$ & $0.223 \pm 0.011$ & $0.168 \pm 0.021$ & $0.622 \pm 0.040$ & $0.252 \pm 0.033$ & $0.251 \pm 0.008$ \\
\hline Kewabhog & $0.806 \pm 0.056$ & $0.228 \pm 0.025$ & $0.210 \pm 0.012$ & $0.572 \pm 0.044$ & $0.228 \pm 0.022$ & $0.188 \pm 0.023$ \\
\hline Shialbhog & $0.788 \pm 0.040$ & $0.283 \pm 0.30$ & $0.195 \pm 0.011$ & $0.615 \pm 0.060$ & $0.216 \pm 0.015$ & $0.196 \pm 0.008$ \\
\hline
\end{tabular}

The average 1000 grain (with husk and without husk) weight also varied according to different Bhog dhan varieties. The grain of Kewabhog showed the highest weight i.e., $20.00 \mathrm{~g}$ (with husk). On the other hand, Tulsibhog showed the lowest grain weight of $12.30 \mathrm{~g}$ (with husk). Similarly highest and lowest weight of 1000 grain (without husk) was observed in Katharibhog (14.30 g) and Ghogubhog (09.03 g) respectively.

Highest and lowest volume of 1000 grain (with husk) was observed in Katharibhog $(24.80 \mathrm{cc})$ and Shialbhog $(10.00 \mathrm{cc})$ respectively. Similarly highest and lowest volume of 
1000 grain (without husk) was observed in Katharibhog $(10.60 \mathrm{cc})$ and Ghogubhog (08.00 cc) respectively.

The colour of the grain (with husk) was found to vary from variety to variety. Kalabhog and Tulsibhog were found to have dark green grains. Mid-buff coloured grains were found in Benibhog, Katheribhog and Shialbhog. In Ghogubhog, it was Golden brown with mid buff shade. In Kewabhog the colour was dark mushroom.

Similarly the colour of the grain (without husk) also differed greatly in all these 7 varieties. It was pista, antique-white in Ghogubhog, raw silk in Benibhog and Shialbhog, fresh sprout in Tulsibhog, sandal wood in Katheribhog, cascade green in Kewabhog (Table 3).

Table 3. Weight, volume and color of grain (with and without husk) of different Joha rice cultivated in Bongaigaon district of Assam

\begin{tabular}{|l|l|l|l|l|l|l|}
\hline Varietal Name & $\begin{array}{l}1000 \text { grains } \\
\text { weight with } \\
\text { husk (gm) }\end{array}$ & $\begin{array}{l}1000 \text { grains } \\
\text { weight } \\
\text { without } \\
\text { husk(gm) }\end{array}$ & $\begin{array}{l}\text { Volume of } \\
1000 \text { grains } \\
\text { with husk (cc) }\end{array}$ & $\begin{array}{l}\text { Volume of } \\
1000 \text { grains } \\
\text { without } \\
\text { husk(cc) }\end{array}$ & Husk colour & $\begin{array}{l}\text { De-husked } \\
\text { grain colour }\end{array}$ \\
\hline Kalabhog & 15.50 & 14.10 & 15.2 & 10.5 & Dark green & Pista \\
\hline Ghagubhog & 12.50 & 09.03 & 10.3 & 08.0 & $\begin{array}{l}\text { Golden } \\
\text { brown with } \\
\text { mid buff } \\
\text { shade }\end{array}$ & $\begin{array}{l}\text { Antique } \\
\text { white }\end{array}$ \\
\hline Benibhog & 12.90 & 10.50 & 15.0 & 09.8 & Mid buff & Raw silk \\
\hline Tulsibhog & 12.30 & 10.70 & 18.5 & 10.0 & Dark green & Fresh sproud \\
\hline Katharibhog & 18.40 & 14.30 & 24.8 & 10.6 & Mid buff & Sandal wood \\
\hline Kewabhog & 20.00 & 16.00 & 15.0 & 10.0 & $\begin{array}{l}\text { Dark } \\
\text { mushroom }\end{array}$ & $\begin{array}{l}\text { Cascade } \\
\text { green }\end{array}$ \\
\hline Shialbhog & 19.90 & 11.00 & 10.0 & 10.2 & Mid buff & Raw silk \\
\hline
\end{tabular}

Table 4. Protein concentration $(\mathrm{mg} / \mathrm{ml})$ of grain and uses of different Joha rice cultivated in Bongaigaon district of Assam

\begin{tabular}{|l|l|l|}
\hline \multicolumn{1}{|c|}{ Varietal type } & \multicolumn{1}{|c|}{$\begin{array}{c}\text { Protein } \\
\text { Concentration } \\
(\mathrm{mg} / \mathrm{ml})\end{array}$} & \multicolumn{1}{|c|}{ Preferred uses } \\
\hline Kalabhog & 1.25 & $\begin{array}{l}\text { For preparation of table rice and sweet } \\
\text { dishes }\end{array}$ \\
\hline Ghagubhog & 0.43 & Sweet dishes \\
\hline Benibhog & 0.78 & Sweet dishes \\
\hline Tulsibhog & 0.85 & Table rice and sweet dishes \\
\hline Katharibhog & 0.74 & Table rice and sweet dishes \\
\hline Kewabhog & 0.18 & Flat rice and sweet dishes \\
\hline Shialbhog & 0.39 & Sweet dishes \\
\hline
\end{tabular}

In case of Protein concentration, highest amount was observed in Kalabhog which was followed by Tulsibhog, Benibhog, Katheribhog, Ghogubhog, Shialbhog and then Kewabhog (Table 4). Regarding the uses it was observed that due to its super fine de- 
husked and deliciousness all the verities are used in preparation of some special dishes like kheer and pulao. Besides, sweet dishes like Kalabhog, Tulsibhog and Katheribhog were found to use in preparation of table rice while Kewabhog in preparation of flatted rice (compressed rice) to take as Jalpan.

\section{CONCLUSIONS}

After conducting a study of seven different varieties of Joha rice growing in the Bongaigaon district of Assam; it was observed that even though all these varieties are more or less similar, each of them possess some unique characteristics which may be helpful in their identification. Again, due to some inherent property, though the Joha rice is highly valued but population pressure and ever increasing demand of higher crop production may lead the farmers to discontinue the practice of cultivating these rice varieties due to poor yield. Therefore, there is an urgent need for characterization and encouraging the farmers to grow these varieties which could help in the in situ on-farm conservation of these important traditional varieties of Bongaigaon.

\section{Acknowledgements}

Thanks are due to UGC (NERO) for providing financial support under Minor Research Project. The author is also thankful to Institutional Biotech Hub and the two research scholars Mr. Pinaki Adhikary and Mr. Bhaskatjyoti Sharma for extending the basic infrastructure and their help in completion of this research activity. Finally, the author offers her gratitude to all the farmers of the study area for their help during field study and for sharing their knowledge on traditional rice varieties.

\section{LITERATURE CITED}

BGR, IOCL, 2010. Official records of Bongaigaon Refinary and Indian Oil Corporation Limited, Bongaigaon.

Buttery, R.G.; Ling, L.C. \& Juliano, B.O. 1982. 2-Acetyl-1-pyrroline: an important aroma component of cooked rice. Chemistry and Industry. 23: 958 - 959.

Choudhury, B.; Khan, M.L. \& Dayanandan, S. 2013. Genetic structure and diversity of indigenous rice (Oryza sativa) varieties in the Eastern Himalayan region of Northeast India. Springer Plus 2: $228-229$.

Das, A.; Tushar; Kesari, V.; Rangan, L. 2010. Aromatic Joha rice of Assam - A review. Agric. Rev. 31(I): 1 - 10.

Harwood, R.R. 1979. Small Farmer Development:- Understanding and Improving Farming Systems in the Humid Tropics. Western Press, Boulder, Colorado.

Hore, D.K. 2005. Rice diversity collection, conservation and management in Northeastern India. Genet. Resour. Crop Evol. 52: 1129 - 1140.

Panda, S.C. 2010. Rice crop science. Agrobios (India), New Delhi.

Sharma, S.D.; Vellanski, V.R.; Hanki, K.L. \& Singh, R.P. 1971. Primitive and current cultivars of rice in Assam: A source of valuable genes. Curr. Sci. 40: 126 - 128. 